This is a self-archived version of an original article. This version may differ from the original in pagination and typographic details.

Author(s): Glavee-Geo, Richard; Shaikh, Aijaz A.; Karjaluoto, Heikki; Hinson, Robert Ebo

Title: Drivers and outcomes of consumer engagement : Insights from mobile money usage in Ghana

Year: 2020

Version: Accepted version (Final draft)

Copyright: ㄷ Emerald Publishing Limited 2019

Rights: In Copyright

Rights url: http://rightsstatements.org/page/InC/1.0/?language=en

Please cite the original version:

Glavee-Geo, R., Shaikh, A. A., Karjaluoto, H., \& Hinson, R. E. (2020). Drivers and outcomes of consumer engagement : Insights from mobile money usage in Ghana. International Journal of Bank Marketing, 38(1), 1-20. https://doi.org/10.1108/ijbm-01-2019-0007 


\title{
Drivers and outcomes of consumer engagement:
}

Insights from mobile money usage in Ghana

\author{
Dr. Richard Glavee-Geo \\ Associate Professor \\ rigl@ntnu.no \\ Department of International Business, \\ NTNU-Norwegian University of Science and Technology, \\ P.O.Box 1517, 6025 Aalesund, Norway
}

\author{
Aijaz A. Shaikh* \\ Postdoctoral Researcher \\ aijaz.a.shaikh@jyu.fi
}

Jyväskylä University School of Business and Economics, P.O.Box 35, FI-40014,

University of Jyväskylä, Finland

\section{Heikki Karjaluoto}

Professor of Marketing

heikki.karjaluoto@jyu.fi

Jyväskylä University School of Business and Economics, P.O.Box 35, FI-40014,

University of Jyväskylä, Finland

\author{
Robert Ebo Hinson \\ Professor of Marketing \\ hinsonrobert@gmail.com \\ Department of Marketing and Entrepreneurship, \\ University of Ghana Business School, \\ P.O.Box LG78, Accra, Ghana
}

* Corresponding Author
+358469516017 


\title{
Drivers and outcomes of consumer engagement: Insights from mobile money usage in Ghana
}

\begin{abstract}
Purpose - The purpose of this study is to examine the drivers of consumer engagement and its consequences via the experiences of mobile money services' users in Ghana, and to discuss its implications for the society, financial service innovation, delivery, and operations. Design/methodology/approach -A pre-tested survey instrument was used with a sample of 595 mobile money services users in Ghana. SmartPLS application was used to analyse the data and report findings.
\end{abstract}

Findings - The study shows that perceived risk, consumer empowerment, subjective norm, performance expectancy, and effort expectancy influence the affect component of consumer engagement and explain around half of its variance. The effect of perceived risk on consumer engagement was counterintuitive. Perceived risk was significant and positive for cognitive processing, whereas the effect was significant but negative for affect. The authors found support for the positive effect of cognitive processing on advocacy intention but no support for its effect on continuous usage. By contrast, affect strongly influenced both advocacy intention and continuous usage of mobile money services.

Practical Implications - We highlight the implications of mobile money services to business and marketing/service managers, policymakers, non-banking entities (such as telecoms and financial technology firms), and to the society in general. We provide important insights into how service providers can manage consumer engagement process and formulate marketing strategies to target and promote this simple, but innovative service to consumers. Moreover, we discuss the societal implications of our study in Ghana, a developing country. We recommend several options for future studies in order to stimulate the research agenda on mobile financial services in general.

Originality/value - The present study shows that although mobile money was initially introduced to help consumers who hitherto have no access to formal banking services, this form of banking has become increasingly popular among various consumer segments as its usage and adoption has increased multifold largely in emerging and developing countries. The main contribution of this study is the development and testing of the 'mobile money customer engagement model.' Moreover, this study shows the key factors that influence the engagement process and the effects of these factors as analyzed within the context of a developing country. 
Keywords Mobile money, Consumer engagement, Continuous usage, Consumer behavior, Ghana.

Paper type Research paper

\section{Introduction}

Innovative service technologies have transformed how individuals, firms, and organizations function today. These developments exert a far-reaching global impact on performance, outreach, competitiveness, and resilience for all industries, including banking and payment services. Inspired by these developments, the services sector, including banking, is witnessing changes in the technological environment with its attendant new business models, which are currently disrupting traditional service elements. Smartphones, phablets, and tablets are facilitating dramatic changes in both service consumption and how consumers interact with different service providers. These portable devices are now in continuous use by consumers when performing different tasks, such as communicating, browsing for information and news, entertainment, banking \& payment services, social networking, and shopping (San-Martín et al., 2016). Unlike entertainment, using portable devices to conduct banking and payment transactions (e.g., sending and receiving money) is ascending in many developing and emerging countries, which often have inadequate branch-oriented banking services network.

The recent phenomenon of using cell phones for accessing and conducting banking and payment transactions remains highly successful due to the rising costs of developing and maintaining expensive bank branches, deploying automated teller machines (ATMs), and applying new technology. These challenges and the developments seen in the increasing use of portable devices strengthen the business case for the mobile money business model in many African countries such as in Kenya, Ghana, and Nigeria, among others. Fortunately, many of these mobile money (also referred to as branchless banking) technology deployments, such as M-Pesa in Kenya and FNB in South Africa, have reached a sustainable scale and have provided a gateway to the digital economy. However, it must be noted that mobile money is not only limited to African countries. Mobile money has become equally popular in Asia, Middle East, and South America and even among individuals from these sub-regions and continents who are now immigrants in Europe and North America; most of them patronize variations of 'branchless banking,' such as 'money transfer'. However, little research has been conducted within the domain of mobile money financial services as 
research and literature have focused on the formal banking and financial services sector. An equally important issue is the lack of knowledge and research on 'mobile money consumer engagement' process. This paper therefore provides increased understanding of the key factors that have an impact on mobile money consumer engagement process and its outcomes, using Ghana as empirical context.

Mobile money is defined as the technology or service that enables a consumer to access, transfer, store, and use money via handheld devices, including mobile phone (Lepoutre and Oguntoye, 2018). Mobile money has had profound implications to people worldwide; perhaps, mobile money has been beneficial to most poor consumers in developing economies as it has bypassed their need to use branch-based banking and in many cases has made the rather unavailable financial services available to them. The introduction of mobile money to the Ghanaian economy has played a key role in promoting financial inclusion (Ghana Banking Survey, 2016) and has provided several benefits to the remote and less privileged population in a myriad of ways. Ghana, therefore, stands out as a good empirical case to examine mobile money services and technology use for several reasons. First, the success of mobile money in Africa, especially in Ghana, is largely due to a greater number of people using handheld devices, including mobile phones, in Africa than in other parts of the world and due to the limited access to or the inaccessibility of formal banking channels, such as branches and ATMs, among Ghanaians. Because of this, cell phones are the only means by which many Africans (Dogbevi, 2010) can access formal banking and payment services. Second, mobile money service providers in Ghana do not require users to open a bank account, which normally requires multiple documents and verifications. By contrast, mobile money services, through agent networks, provide instant, cheap, and relatively safe means of transferring money, offer shortened transaction times, and charge low transaction costs from the poor and unbanked population (Ghana Banking Survey, 2016). Third, this paper based on the sample studied argues that the introduction and usage of mobile money transcends many segments of the population and is not only limited to the poor, underbanked or financially excluded population. Fourth, developing and fast emerging markets are presenting significant departures from the assumptions of Western or developed world theories that challenge our conventional wisdom (Burgess and Steenkamp, 2006). Consequently, findings from the Ghanaian setting may be applied to other countries and contexts. 
In the context of mobile money services, we define consumer engagement as a consumer's positively valenced mobile application-related cognitive, emotional, and behavioral activity during or associated with the focal consumer and mobile application-based interactions (Hepola et al., 2016). Consumer engagement has received increasing attention from the industry and researchers; recently, consumer engagement (also referred to as user engagement or customer engagement) has been examined in various technology usage contexts, such as mobile commerce application (McLean, 2018), online brand communities (Ibrahim et al., 2017), and mobile payment applications (Hepola et al., 2016). This increasing attention to consumer engagement is largely due to the fact that, unlike customer satisfaction, consumer engagement targets more long-term interactions and encourages customer loyalty and advocacy through word of mouth. Therefore, when a relationship between a firm and a customer is satisfactory and creates an emotional bond, such relationship progresses to the engagement stage with the potential to generate more sales, to ensure a lifetime of profitable loyalty (Pansari and Kumar, 2017), and to increase firm value (Verhoef et al., 2010).

Considerable academic effort has been invested to study consumer engagement in social media technologies and retail banking delivery channels and services, such as online/Internet banking and mobile banking (e.g., Mullan et al., 2017; Oruç and Tatar, 2017; Rawashdeh, 2015; Tam and Oliveira, 2016; Ibrahim et al., 2017). However, consumer engagement in the context of mobile money remains unexplored.

This study covers mobile money services that are not limited to the unbanked and underbanked segments of society, but which are also used by the highly literate consumer segments. This study provides ample evidence to show that popularity of mobile money usage is not limited to the underprivileged. Mobile money service is a viable and profitable business that has the potential to contribute to the financial viability of banks, financial institutions, and FinTechs, among other service providers. In view of the above, we seek to address the following research questions:

RQ1: Which key factors influence consumer engagement process?

RQ2: How do the dimensions of customer engagement (i.e. cognitive processing and affect) explain the advocacy intention and continuous usage of mobile money services in Ghana? 
RQ3: What are the implications of mobile money adoption and usage to businesses (banking and non-banking) and policy makers?

This study aims to contribute to the on-going debate on mobile money services, which have permeated every sector of the economy largely in emerging and developing markets. In addition, this study examines how consumer engagement influences the sustained usage of mobile money services in Ghana. Moreover, it contributes to the literature on antecedents and consequences of consumer engagement.

This study offers important theoretical, managerial, and societal implications for business, marketing managers, policymakers (including regulatory bodies), non-banking entities, such as telecoms, financial technology firms (FinTech) start-ups, service providers, and society in general. It highlights how service providers can manage the engagement process. For instance, understanding the behavior and experiences of segments of the population that are financially excluded (i.e. non-access to the formal/documented banking services) provides valuable insights for strategy formulation concerning financial inclusion (i.e. access to the formal/documented banking services). It also provides insights into the best ways to promote a new payment system to potential consumers (Shaikh et al., 2015).

Depending on the nature of the consumer, regulations in place, and technology in use, mobile money has been referred to as either branchless banking, easypaisa, corresponding banking, over-the-counter banking, or agent banking (Diniz et al., 2012), with the same intended purpose and objective.

Our paper is organized as follows: We begin by discussing mobile money as used within and outside Africa, and then we describe the consumer engagement model. Next, we formulate our hypotheses and present our research methodology, analysis, and results. We then discuss our findings in the light of the published findings, draw our conclusion based on our study objectives, and recommend directions for future research.

\section{Literature review}

Mobile money within and outside Africa

According to the Global System for Mobile Association (GSMA, 2017), the global mobile money industry processes transactions worth over a billion dollars a day and generates direct 
revenues of over USD 2.4 billion. Moreover, over 690 million are registered mobile money account holders worldwide.

Since the launch of M-Pesa, the first mobile money service in Kenya, pro-poor innovations (e.g., mobile money) were adopted rapidly in subsistence marketplaces, leapfrogging the traditional banking and payment services (Riley, 2018; Hasan et al., 2019). Mobile money refers to the use of cell phones to perform financial and payment functions, such as remittances transfers, airtime purchase, utility bill and school fee payments, and savings (Murendo et al., 2018). Dermish et al. (2011) provide a more comprehensive definition of mobile money (also called branchless banking); they consider mobile money as an innovative banking channel that allows consumer-oriented companies, including banks, to offer financial and other customer-friendly solutions outside traditional bank premises, with handheld devices as primary channel (Figure 1 depicts mobile money as an innovative technologydriven business model). From these definitions, cell phones clearly now serve as virtual bank cards, as point-of-sale (POS) terminals, and as internet banking terminals (Mothobi and Grzybowski, 2017) that enable transfers to be done remotely.

A few key factors that have driven the development and introduction of mobile money in developing and emerging countries, including African countries, are infrastructure deficiencies, the diminishing financial inclusion landscape that inhibits promotion of formal banking, and payment practices among the less privileged population, also known as the base of the pyramid (Berger and Nakata, 2013), which consists of the underbanked and unbanked segments. However, we argue that this assertion is gradually changing as mobile money has become commonly used even among the highly educated and professional/employed segments of the population as demonstrated by the current study.

[Insert Figure 1 about here]

Unlike other innovative banking services, which are largely controlled and managed by diligently regulated banking firms, mobile money motivates greater collaboration and partnership between banking and non-banking entities, such as telecom companies and FinTechs. Moreover, compared with branch-based banking services, ATM, and Internet banking, a mobile money network consists of three major elements, as follows: (1) designated retail stores and agents usually appointed or designated by the banking companies, telecoms, and microfinance institutions; these mobile money agents are accessible to low- 
income customers to provide banking and payment services on a daily basis; (2) an electronic payment and telecommunication infrastructure; and (3) an accounting platform, which is primarily provided by either traditional commercial or microfinance banks. Retail establishments or mobile money agents usually act as intermediaries between banks/microfinance institutions and their customers. However, according to Jayo et al. (2012), payment infrastructure is the only element that can be operated by either a bank or a microfinance firm to facilitate mobile money transactions.

\section{Consumer engagement theory}

Consumer engagement has hypothetical roots within the extended domain of relationship marketing that emphasize the notions of interactivity and customer experience (Vivek et al., 2012). Consumer engagement is considered as the creation of a deeper and meaningful connection between the company and the customer (Khan et al., 2016). It is widely believed that a well engaged customer plays a key role in viral marketing activity and by providing constant referrals and recommendations (Brodie et al., 2011) and increasing advocacy intention for a specific products, services, and brands to others either face-to-face and on various channels including social media.

Pansari and Kumar (2017) define consumer engagement as "the mechanics of a consumer's value addition to the firm, either through a direct or/and indirect contribution" (p. 295). Others (Hollebeek et al., 2014; Abdul-Ghani et al., 2018) suggest that consumer engagement or consumer brand engagement expresses the cognitive, emotional, and behavioral connection a user or customer has with a firm or brand.

The consumer engagement largely provides a multidimensional perspective consists of cognitive, emotional, behavioral, and social elements, but according to Brodie et al. (2011), a good number of studies have provided a unidimensional perspective consist of either the emotional, cognitive, or behavioral aspect of engagement.

For the sake of this study, the terms 'customer engagement,' 'consumer engagement,' and 'user engagement' are used interchangeably in this paper. Although, consumer engagement is conceived as a behavioral, cognitive, and emotional process (Dessart et al., 2015), in this research, we focus on two key consumer engagement dimensions: cognitive processing and affect. 


\section{Conceptual model and hypotheses development}

In accordance with Mollen and Wilson's (2010) conceptualization, we have based our investigation of the antecedents and consequences of consumer engagement on psychological factors. Although we did not hypothesize the effects of perceived risk (see Figure 2), we included perceived risk in the model due to the important role that risk plays in the adoption of mobile-based innovative technology products and services. We also controlled for usage experience, usage frequency, education, income, and age.

[Insert Figure 2 about here]

Factors predicting the cognitive processing dimension of consumer engagement According to Midha (2012), consumer empowerment is related to user's perception of the extent to which he/she can control the distribution and use of his/her personal identifying information. Consumers consider empowerment the ability to draw forth positive emotions (affect), such as hope and happiness. These findings suggest that greater consumer empowerment with expanded information capabilities will lead to greater cognitive processing.

Subjective norm is similar to the antecedent social influence and social norm. Subjective norm refers to the perceived social pressure about whether to adopt or accept a specific behavior such as adoption and usage of an innovative service such as mobile money (Ajzen, 1985; Glavee-Geo et al., 2017). The cognitive aspect of subjective norm helps individuals evaluate situational conditions and consequences, such as the possibility of and/or difficulty in implementing one particular behavior (Jalilvand et al., 2011). Receiving a plethora of information and opinions from family and friends about something, such as the use of mobile money services, will lead to a more rigorous information search, especially with cognitive pressure. Consequently, it is logical that subjective norm will increase consumers' cognitive processing.

In the m-banking context, performance expectancy reflects the user's perception of performance improvements, such as convenient payment options, fast response, and service effectiveness (Zhou et al., 2010). In the context of Internet banking, performance expectancy refers to the degree to which consumers believe that using Internet banking could help them 
either make a profit or save money while conducting online banking tasks (Venkatesh et al., 2003). This study particularly considers performance expectancy as the degree to which an underbanked or unbanked consumer believes that the perceived usefulness of using mobile money services will provide benefits as well as improve his/her performance. These benefits can include the following: "... is useful in my daily life," “... will increase my productivity," and "... will help me save time."

By contrast, effort expectancy is defined as the user's perception of how difficult it is to use any product or service (Zhou et al., 2010). Venkatesh et al. (2003) found that consumer adoption and usage of an information system, such as m-banking, is largely influenced by four major factors: performance expectancy, effort expectancy, social influence, and facilitating conditions. Regarding the relationship between perceived usefulness and cognitive processing, Hew and Kadir (2016) found that perceived ease of use and perceived usefulness influence immersion and cognitive processing. This implies that the ease of use of either a service, product, innovation, or technology should have an impact on the cognitive processing of information. This argument brings us to our first hypothesis:

H1: Consumer empowerment (H1a), subjective norm (H1b), performance expectancy (H1c), and effort expectancy (H1d) have a positive effect on consumer cognitive processing.

\section{Factors predicting the affect dimension of consumer engagement}

After examining brands and consumer engagement in online brand communities, Wirtz et al. (2013) found that the overall quality of brand communities' relationships with a group is higher when they demonstrate greater engagement and subjective norm. Similarly, consumer engagement in sustainable technology is influenced by attitude, subjective norm, perceived behavioral control, and personal norms (Gangale et al., 2013). Additionally, subjective norm is considered a significant predictor of consumer engagement (de Oliveira et al., 2016).

Cognitive pressure is considered interconnected with the affect (or the emotional aspects) of an individual's attitude. Here, it is largely believed that affect plays an important role in the adoption and usage of information systems, such as mobile banking and mobile money services. 
According to Li et al. (2012), subjective norms have a positive effect on emotion during mobile device usage. In the context of e-commerce use, Smith (2008) and Kim et al. (2016) assert that ease of use influences the motivation and affect of consumers. This is true in the case of mobile money services, which is available to those who cannot access formal banking services, such as branch banking and ATMs, in remote areas. Consequently, it is expected that people develop affect (or positive emotions) toward mobile money services when using these services to remit funds to their family and friends. Under these circumstances, it is likely that the performance expectancy and effort expectancy of mobile money services will increase consumers' affect for the service. Based on these findings, we propose the following hypotheses:

H2: Consumer empowerment (H2a), subjective norm ( $\mathrm{H} 2 \mathrm{~b})$, performance expectancy $(\mathrm{H} 2 \mathrm{c})$, and effort expectancy $(\mathrm{H} 2 \mathrm{~d})$ have a positive effect on consumer affect.

\section{Effects of cognitive processing on advocacy intention and continuance usage}

Cognitive processing is the consumer's level of thought processing and elaboration when interacting with a specific information system, such as m-money, social media, and/or various brands (Brodie et al., 2011). Advocacy intention is defined as the expressive response of consumer loyalty that is motivated by emotional factors and/or perceived social benefits (Jones et al., 2008). Conversely, continuous usage of either a product or service after either initial acceptance or adoption occupies an important position; thus, it has been examined extensively in the information systems and marketing literature.

For example, continuous usage has been investigated in the context of m-banking (Shaikh et al., 2015), mobile broadband (Kongaut and Bohlin, 2016), and mobile social apps (Hsiao et al., 2016). Research has long emphasized the need to investigate m-banking continuous usage (Shaikh et al., 2015). Moreover, in the context of m-banking and m-payments, a direct relationship between cognitive processing and continuous usage intention has been examined by Hepola et al. (2016). We intend to further examine these associations and therefore propose the following hypotheses:

H3: Cognitive processing has a positive effect on advocacy intention (H3a) and continuous usage (H3b). 


\section{Effects of affect on advocacy intention and continuance usage}

Affect - which is connected to the demand for new stimuli (Cotte and Wood, 2004) - in the mobile context refers to the extent of a consumer's positive mobile application-related affect regarding a particular consumer and mobile application interaction (Hollebeek et al., 2014). Concerning consumer affect, positive emotional responses, such as pleasure, may lead to approach responses (Mehrabian and Russell, 1974); thus, emotional responses can positively affect users' behavior (Oliver, 1997). As argued by Hepola et al. (2016), positive feelings about a product or service, such as mobile application use, lead to an increased intention to continue using the mobile-based service. In addition, Hollebeek et al. (2014) found that affect influences the usage intentions of social media.

Similar to these findings, Hepola et al. (2016) found a positive relationship between the affective (emotional) dimension of consumer engagement and continuous usage intention. As argued by Vivek et al. (2012) and Hollebeek et al. (2014), the cognitive dimension of consumer engagement relates to positive experiences. Nonetheless, contrary to their expectations, Hollebeek et al. (2014) found that cognitive processing did not affect usage intention in the context of social media. Hepola et al. (2016) examined the relationship between consumer engagement (including its three dimensions, i.e. cognitive processing, affect, and activation) and the continuous usage of mobile-based products and services, including m-banking applications. Here Hepola et al. found that affect and activation have a positive impact on continuous usage intention. Considering these somewhat contradictory prior results, in which the relationship between cognitive processing and continuous usage is somewhat unclear, more research is needed to test this relationship. Subsequently, this leads to our fourth hypothesis:

H4: Affect has a positive effect on advocacy intention (H4a) and continuous usage (H4b).

\section{Research methodology}

\section{Research setting}

The survey measurement scales were extracted from previous studies and modified to suit the mobile money context. To ensure the instrument validity of the measurement scales, a pretest of the questionnaire was carried out on working professionals in Ghana. After a thorough review, some items were revised based on participants' suggestions to ensure the clarity of 
the items. All items were measured on a 7-point Likert scale, ranging from strongly disagree (1) to strongly agree (7). Table 1 shows the constructs, measures, and factor loadings.

[Insert Table 1 about here]

\section{Sample and data collection}

Data were collected mostly from college students, graduate students, and workers of the University of Ghana; these participants do avail mobile money services. Three teaching assistants randomly approached potential survey participants to ask for their consent to be a part of the survey. A total of 869 potential respondents were approached, and 595 survey responses were received during the last quarter of 2016. Two hundred and sixteen potential participants declined to participate because they do not use mobile money services. The sample consisted of $53.1 \%$ males and $46.9 \%$ females. Almost $90 \%$ of the respondents were between 18 and 35 years of age. However, a few participants (3\%) were over 45 years of age. Close to $70 \%$ of the respondents had a bachelor's degree. While checking the cell phone usage in Ghana, we found that around $53 \%$ of the survey participants were using a cell phone for more than 4 years, while approximately $19 \%$ had used a cell phone for less than a year. In addition, over $70 \%$ of the respondents had more than 5 months of mobile money services usage experience. We present the sample's demographic characteristics as shown in Table 2. The demographic profiles provide evidence to support our view that the introduction and usage of branchless banking transcends many segments of the population.

[Insert Table 2 about here]

\section{Common method variance}

Before testing the hypotheses, we conducted statistical tests to ensure that our findings were not biased by using common method variance (CMV) (Podsakoff et al., 2003). As suggested by Hulland et al. (2018), the potential CMV was limited by not revealing the true purpose of the study, mixing the items in the questionnaire, and keeping the identities of the respondents confidential. Regarding post hoc methods to detect CMV, we modified the partial least squares (PLS) path model to reflect that we considered each indicator variable as a factor linked to its second order construct. The method construct, which is a new factor, was then added, with its indicators including all the indicators used in the latent variables in the research model (Kemery and Dunlap, 1986; Liang et al., 2007). The results showed that the variance explained by indicators in the common method construct was only 0.02 , which 
shows that CMV bias did not considerably influence our study results. Based on the various approaches we used in testing CMV, we concluded that method variance biases are less likely to confound the interpretations and findings of this study.

\section{Analysis}

The measurement model was evaluated via the PLS technique using SmartPLS 3.0 (Ringle et al., 2015). First we examined the items' internal consistency and scale reliability by using Fornell and Larcker's (1981) composite reliability index. Here, we found that the composite reliability values for all constructs used in this study exceeded the acceptable value of 0.7 (Hair et al., 2016). From Table 1, the factor loadings are all significant $(\mathrm{p}<0.001)$ and greater than 0.70 , except the indicator NOM3, which had a loading of 0.653 . We also assessed the measurement model in regards to convergent and discriminant validity. We evaluated convergent validity based on the average variance extracted (AVE) approach (Fornell and Larcker, 1981), where a value of 0.5 and above indicates an acceptable level. The AVE — by our measures — ranged from 0.69 to 0.83 , which were above the acceptable value of 0.5 . In addition, we assessed the discriminant validity of the latent variables in the PLS path model using the heterotrait-monotrait ratio of correlations (HTMT) (Henseler et al., 2015). Our analysis showed that the HTMT values were all below .85, which shows that discriminant validity was established between any two of the constructs (Hair et al., 2017; Hair et al., 2018; Henseler et al., 2015).

\section{Results}

\section{Structural model assessment}

We hypothesized that consumer empowerment (H1a), subjective norm (H1b), performance expectancy (H1c), and effort expectancy (H1d) have a positive effect on consumer cognitive processing. The results (Table 3) confirm these paths, except for H1a. The effects of subjective norm $(\beta=0.26, p<0.001)$ and effort expectancy $(\beta=0.25, p<0.001)$ were the strongest. Perceived risk was positively related to cognitive processing $(\beta=0.11, p<0.01)$. However, H1 a was insignificant $(\beta=0.07, p>0.05)$. H2 proposed that consumer empowerment (H2a), subjective norm (H2b), performance expectancy (H2c), and effort expectancy (H2d) have a positive effect on affect. All these relationships were supported by the data. The effect of perceived risk on consumer engagement was counterintuitive, while the effect was significant and positive for cognitive processing $(\beta=0.11, p<0.01)$ but significant and negative for affect $(\beta=-0.14, p<0.001)$. 
The findings show the important role of subjective norm in the use of mobile money services in the research setting. The effect of effort expectancy on cognitive processing and affect was supported.

Regarding the outcomes of consumer engagement, H3 states that cognitive processing affects advocacy intention (H3a) and continuous usage (H3b). The results support the positive effect of cognitive processing on advocacy intention $(\beta=0.11, p<0.05)$ but not the hypothesized effect of cognitive processing on continuous usage (Table 3). H4 hypothesized the positive influence of affect on advocacy intention (H4a) and continuous usage (H4b) was confirmed (H4a: $\beta=0.46$; H4b: $\beta=0.39$, both at $p<0.001$ ). An inspection of the variance inflation factor (VIF) values demonstrates that multicollinearity is not a problem; therefore, no assumption was violated in assessing the structural models. All VIF values were less than the more conventional rule of thumb value of five (Hair et al., 2016). Figure 3 shows the results of the final estimated model.

[Insert Figure 3 about here]

[Insert Table 3 about here]

The significant factors predicting cognitive processing $\left(\mathrm{R}^{2}=0.31\right)$ were perceived risk, subjective norm, performance expectancy, and effort expectancy, while the same factors, alongside with consumer empowerment, also strongly predicted affect and explained $45 \%$ of its variance. Perceived risk, cognitive processing, affect, and covariates (usage frequency and income) predicted advocacy intention. Thus, usage experience $(\beta=0.10, \mathrm{p}<0.01)$ and usage frequency $(\beta=0.10, \mathrm{p}<0.05)$ had a slight positive effect on advocacy intention. The effect of the controls (education, usage experience, usage frequency, income, and age) on continuous usage was insignificant (see Table 3). Finally, while affect had a significant effect on continuous usage $(\beta=0.39, \mathrm{p}<0.001)$, the effect of cognitive processing on continuous usage was insignificant $(\beta=-0.03, \mathrm{p}>0.05)$. A summary of the structural model results is shown in Table 4.

[Insert Table 4 about here]

\section{Discussion and conclusion}


Mobile-based financial delivery systems and technologies are quite common and popular on the African continent. The introduction of mobile money to the Ghanaian economy has played a key role in the push for financial inclusion (Ghana Banking Survey, 2016) and provided several benefits to the remotely located population in a myriad of ways. For instance, providers of the service in Ghana do not require the user to open a formal bank account. Mobile money provides a cheap and relatively safe means of transferring money, shortening transaction times, and reducing transaction costs to the poor and unbanked (Ghana Banking Survey, 2016).

This study provides important insights into consumer behavior when using mobile money services and how the drivers of consumer engagement generate the advocacy intention, and the continuous usage of MM services usage in Ghana. To achieve the research objective, we developed and tested a series of hypotheses using the survey data of 595 mobile money users in Ghana.

\section{Theoretical implications}

This study makes important contributions to theory/research by showing that while perceived risk, consumer empowerment, subjective norm, performance expectancy, and effort expectancy are significantly related to affect (all hypothesized relationships have a t-value $>$ 3.29 for two-tailed test and $p<0.001$ ), the same antecedent variables showed mixed results regarding cognitive processing. In addition, the explanatory power of these variables differs, that is, variation in affect is $45 \%$ whereas $31 \%$ in cognitive processing. Thus, this study theoretically shows that the antecedent effects of perceived risk, consumer empowerment, subjective norm, performance expectancy, and effort expectancy on cognitive processing and the affect dimensions of customer engagement differ. These effects are stronger and more consistent for affect than for cognitive processing.

Prior research (e.g., de Oliveira et al., 2016; Gangale et al., 2013) has confirmed the positive relationship between subjective norm and consumer engagement. Here, Gangale et al. (2013) stated that consumer engagement in sustainable technology is influenced by attitude, subjective norm, perceived behavioral control, and personal norm. Similarly, de Oliveira et al. (2016) found significant relationship between subjective norm and user engagement with social media (Facebook). In addition to subjective norm, we found that performance expectancy (akin to perceived usefulness) of mobile money services is a significant 
antecedent of consumer engagement (cognitive processing and affect). This suggests that performance expectancy increases consumer engagement with mobile money services. Consumer empowerment is key to the use of mobile money services. Empowering the users of the service by using service agents, who form important nodes in the network, positively impacts the 'emotional' component of the engagement process, but it does not create much effect on the cognitive component. In addition, the simple nature of the service has had less impact on the cognition of the group consisting of a high number of highly educated respondents compared with its effect to group consisting of less educated respondents. This could explain the insignificant association between consumer empowerment and cognitive processing in the empirical setting. Furthermore, the effect of cognitive processing on advocacy intention was weak whereas its effect on continuous usage was insignificant compared to that of affect.

After five antecedent factors were employed, the 'mobile money customer engagement model' gives better explanatory power for the affect component than for the cognitive dimension. This model, which was developed and tested in this study, can be used in further research and bank marketing strategy formulation. In terms of research, conceptualizing customer engagement as a multidimensional construct could provide a better insight into the study of a phenomenon. In engaging consumers, service providers can more easily influence the engagement process by appealing to consumers (i.e. providing stimuli) regarding service delivery through emotional aspects than through cognitive components.

We also sought to confirm the negative relationship between perceived risk and consumer engagement. We expected perceived risk to have negative effect on consumer engagement. However, the empirical results show positive effect on cognitive processing and a negative effect on affect. The 'mixed' effect of perceived risk on consumer engagement can be explained by the fact that while perceived risk reduces affect, it nevertheless increases the cognitive processing component of consumer engagement. This is an interesting finding and contribution; perceived risk therefore stimulates the 'thought' processes of the consumer decision-making process. These findings are logical due to the context of the mobile money services in a developing country where the sending and receiving of money mediated by technology and service agents could make users skeptical and apprehensive due to the nature of the service. The uneasiness and fear that something might go wrong during the use of the service could explain the positive effect of perceived risk on cognitive processing. However, 
the ability of users to learn about the service and to understand the processes involved could explain the continuous use of the service. Prior research (McLean, 2018) has found direct relationship between the perceived usefulness, perceived ease of use, and consumer engagement with an m-commerce application.

Regarding the outcomes of consumer engagement, our results show support for the positive effect of cognitive processing on advocacy intention. However, no support was found for the relationship between cognitive processing and continuous usage. These results are partially in line with the findings reported by Hepola et al. (2016), who tested the effects of users' selfcongruence and personal innovativeness on consumer engagement in the context of $\mathrm{m}$ banking and mobile payment (m-payment) applications and concluded that cognitive processing does not affect continuous usage intention. This finding is also in line with Hollebeek et al. (2014), who showed that cognitive processing did not influence usage intention concerning social media.

This approach is further evident from the consequent effects in which the affect component of engagement has a stronger effect on both advocacy intention and continuous usage compared to cognitive processing. This does not mean that the cognition component is of less importance; perceived risk significantly increases cognitive processing and limits advocacy intention, as shown by the results of this study.

\section{Managerial, and regulatory implications}

The findings also provide valuable information for practitioners, including other service providers in the delivery of financial services. Mobile money is a recent phenomenon. Hence, in the early stages of innovation or technology adoption and with a target audience (regarding potential customers) with relatively low to high literacy (based on the study's sample characteristics), the use of the affective component in stimulating engagement has a higher chance of success (increased continuous usage of the service) and therefore value to the company. One of the important implications is that the advent of new technologies has made it possible for both non-banking and financial technology firms to introduce innovative banking services such as branchless banking targeting potential customers of all segments. The challenge is that financial institutions with the hitherto physical 'brick and mortar' business model stands the chance of losing potential customers if they don't consider the impact these new business models can have on their current operations and services. The 
competition from the new financial technology mediated business models pose a threat to the old established banks that lack service innovation. Likewise, for financial institutions and financial technology firms introducing new service innovations (such as branchless banking) to keep up with the competition, must consider consumer engagement as an important strategy for business sustenance and sustainability. This is because consumer/customer engagement targets long-term interaction with the purpose of customer value addition, increased sales, and an eventual increase in firm value (Pansari and Kumar, 2017; Verhoef et al., 2010).

Another important implication has to do with marketing strategy formulation. Strategies for segmenting the different segments of branchless banking customers (the underbanked, banked, excluded, poor, affluent, educated, professional/employed segments) and targeting and positioning the branchless service to these segments should involve services marketing/operational plans for subsequent customer engagement. Banks would do well to empower their customers, which would encourage emotional engagement with mobile money services and therefore increase its usage. This emotional engagement will also increase consumer satisfaction and loyalty. For example, consumer empowerment can be achieved through financial literacy and well-being and consumer education. Concerning regulatory implications, given the significance of mobile money services in reaching the masses and infusing countries with economic activities, it is critical that developing economies provide an accessible institutional as well as regulatory framework for the development of this innovative technology/service.

Regarding regulatory implications, it is widely believed that the revised Payment Services Directive (known as PSD2) issued by the European Commission and implemented in early 2018, will create several challenges for the diligently regulated banking industry. Similarly, these regulatory developments will significantly affect the mobile money, mobile payment, and other related business models. For example, these regulations require the banking companies to share their account holder data with third party and mostly the non-banking actors, such as Telecoms, FinTech, etc., thereby allowing these non-banking entities to gain as well as retain control of the value network that serves customers. Future developments, as well as the strategic planning documents both prepared and followed by banking companies, should accommodate these developments and assess their impact on future business growth.

\section{Societal implications}


With a global installed base of over 4 billion handheld devices in use (App Anni Mobile Report, 2019), mobile technology can go a long way in providing formal banking and other financial services to different consumer segments globally. Since 2007, mobile money technology, services, and enabling regulations expand the banking and financial services outreach within and outside Africa by motivating non-banking entities, such as Fintech, to collaborate with banking institutions to develop and deploy mobile payment products and services for a larger consumer segment. In Sub-Saharan Africa, access to traditional banking channels is very limited, and due to unstable infrastructure, internet facilities are highly limited and virtually non-existing. Under these circumstances, mobile technology plays an important role in the everyday life of consumers and has become a primary channel for accessing and using formal banking services.

Moreover, formal but highly convenient banking services are widely considered as 'blessing' by radically transforming the lives of a considerable portion of underbanked population (Lepoutre and Oguntoye, 2018); they also change the socio-economic condition of many in emerging and developing countries by way of documenting financial transactions, promoting savings, facilitating easy and quick transfers and payments, and creating a new revenue stream for banking and non-banking entities.

\section{Limitations and future research directions}

This study is not without limitations such that in interpreting the findings of the paper, the following points should be taken into consideration. First, our study used a single-sourced data at one point in time from segments that are mostly in the age group 18-35, more educated and some of which are professional working people. Some of these respondents do not qualify for the so-called 'unbanked, underbanked or excluded' or 'bottom of the pyramid' segments that normally used to be the target of branchless banking. The sample we investigated in the current study shows that the use of branchless banking is not a preserve of only the poor, low literate and financially excluded population. Branchless banking adoption and usage is becoming popular, if not, has already reached high levels of adoption in most developing countries (and even in developed countries in different forms-e.g. Vipps in Norway). Thus, the cross-sectional nature of the study could be a limitation. It is possible that with a longitudinal study targeting the various segments of the population regarding the process and mechanisms of customer engagement, its antecedents and consequent effects can be studied in a more dynamic manner. This will help increase our understanding of the usage and adoption of branchless banking in relation to time since this business model is still 
evolving. Second, as with any survey research, other factors could potentially explain our outcome constructs in this context. It is also notable that mobile money technology/service use is recent trends in most developing countries. The need to engage consumers is a key factor in continuous usage and recommendation of the service to other potential customers. However, unlike m-banking and Internet banking, mobile money depends on the use of the agents' networks; therefore, the quality of service provided by agents has implications for customer satisfaction and retention. Third, the focus of this study was to examine user perspectives. Future studies could evaluate mobile money agents who serve as intermediaries between consumers and either banking companies or microfinance institutions. This would provide valuable insights into the business-to-business context.

Fourth, service design has been conceptualized as an antecedent of service quality due to its unique role in creating customer experiences (Andreassen et al., 2016). Future studies could explore the service design-customer experience model (Andreassen et al., 2016, p. 24) within the context of mobile money.

Fifth, qualitative studies on the motivations and service experiences of consumers using mobile money services could provide in-depth data on the mechanisms of mobile money and technology use. In addition, future studies could also research the personality traits of mobile money agents and how these traits impact consumer engagement (regarding agents' conation/actions/behavior) as well as their consequential effect on agent performance.

Sixth, while research on the link between personality traits and consumer engagement is lacking (Islam et al., 2017), it is even more so in the context of innovative service adoption, such as mobile money technology/service use. Finally, service recovery after customer dissatisfaction (Andreassen, 2000) within the context of challenges, such as digital mobile money fraud, among other negative practices that mitigate against the service and lead to customer dissatisfaction, is a potential future research option that is worthy of consideration.

\section{References}

Abdul-Ghani, E., Hyde, K. F. and Marshall, R. (2018), "Conceptualising engagement in a consumer-to-consumer context”, Australasian Marketing Journal (In press). 
Ajzen, I., (1985), "From intentions to actions: A theory of planned behavior", In J. Kuhl \& J. Beckman (Eds.), Action control: From cognitions to behaviors (pp. 11-39). New York: Springer.

Andreassen, T. W. (2000), “Antecedents to satisfaction with service recovery”, European Journal of Marketing, Vol. 34 No. 1/2, pp. 156-175.

Andreassen, T. W., Kristensson, P., Lervik-Olsen, L., Parasuraman, A., McColl-Kennedy, J. R., Edvardsson, B. and Colurcio, M. (2016), "Linking service design to value creation and service research”, Journal of Service Management, Vol. 27 No. 1, pp. 21-29.

Brodie, R. J., Hollebeek, L. D., Juric, B. and IIic, A. (2011), “Customer engagement: Conceptual domain fundamental propositions and implications for research", Journal of Service Research, Vol. 14 No. 3, pp. 252-271.

Brodie, R. J., Hollebeek, L. D., Jurić, B. and Ilić, A. (2011), “Customer engagement: conceptual domain, fundamental propositions, and implications for research", Journal of Service Research, Vol. 14 No. 3, pp. 252-271.

Berger, E., and Nakata, C. (2013). Implementing technologies for financial service innovations in base of the pyramid markets. Journal of Product Innovation Management, Vol. 30 No. 6, pp. 1199-1211.

Burgess, S. M. and Steenkamp, J. B. E. (2006), "Marketing renaissance: How research in emerging markets advances marketing science and practice”, International Journal of Research in Marketing, Vol 23 No. 4, pp. 337-356.

Cotte, J. and Wood, S. L. (2004), "Families and innovative consumer behaviour: A triadic analysis of sibling and parental influence", Journal of Consumer Research, Vol. 31, pp. 7885.

de Oliveira, M. J., Huertas, M. K. Z. and Lin, Z. (2016), "Factors driving young users' engagement with Facebook: Evidence from Brazil”, Computers in Human Behavior, Vol. 54, pp. 54-61. 
Dermish, A., Kneiding, C., Leishman, P. and Mas, I. (2011), "Branchless and mobile banking solutions for the poor: a survey of the literature”, Innovations, Vol. 6 No. 4, pp. 81-98.

Dessart, L., Veloutsou, C. and Morgan-Thomas, A. (2015), “Consumer Engagement in Online Brand Communities: A Social Media Perspective”, Journal of Product \& Brand Management, Vol. 24 No. 1, pp. 28-42.

Diniz, E., Birochi, R. and Pozzebon, M. (2012), "Triggers and barriers to financial inclusion: The use of ICT-based branchless banking in an Amazon county", Electronic Commerce Research and Applications, Vol. 11 No. 5, pp. 484-494.

Dogbevi, E. (2010), "More in Africa use mobile phones than on any other continent", available at: https://www.ghanabusinessnews.com/2010/01/04/more-in-africa-use-mobilephones-than-on-any-other-continent/ (accessed November 10, 2018).

Fornell, C. and Larcker, D. F. (1981), "Evaluating structural equation models with unobservable variables and measurement error", Journal of Marketing Research, Vol. 18 No. 1, pp. 39-50.

Gangale, F., Mengolini, A. and Onyeji, I. (2013), “Consumer engagement: An insight from smart grid projects in Europe”, Energy Policy, Vol. 60, pp. 621-628.

Ghana Banking Survey (2016), "How to win in an era of mobile money", available at: https://www.pwc.com/gh/en/assets/pdf/2016-banking-survey-report.pdf (accessed December $15,2018)$.

Glavee-Geo, R., Shaikh, A. A. and Karjaluoto, H. (2017), "Mobile banking services adoption in Pakistan: are there gender differences", International Journal of Bank Marketing, Vol. 35 No. 7, pp. 1088-1112.

GSMA (2017). State of the Industry Report on Mobile money. https://www.gsma.com/mobilefordevelopment/wpcontent/uploads/2018/05/GSMA_2017_State_of_the_Industry_Report_on_Mobile_Money_F ull_Report.pdf 
Hair Jr, J. F., Hult, G. T. M., Ringle, C. M. and Sarstedt, M. (2016), A primer on partial least squares structural equation modelling (PLS-SEM), Sage Publications.

Hair Jr, J.F., Hult, G.T.M., Ringle, C.M. and Sarstedt, M.A. (2017), Primer on Partial Least Squares Structural Equation Modeling (PLS-SEM), Sage, Thousand Oaks, CA.

Hair Jr, J.F., Sarstedt, M., Ringle, C.M. and Gudergan, S.P. (2018), Advanced Issues in Partial Least Squares Structural Equation Modeling, SAGE Publications.

Hasan, R., Lowe, B., and Petrovici, D. (2019). An empirical comparison of consumer innovation adoption models: implications for subsistence marketplaces. Journal of Public Policy \& Marketing, Vol. 38 No. 1, pp. 61-80.

Henseler, J., Ringle, C.M. and Sarstedt, M. (2015), “A new criterion for assessing discriminant validity in variance-based structural equation modelling", Journal of the Academy of Marketing Science, Vol. 43 No. 1, pp. 115-135.

Hepola, J., Karjaluoto, H. and Shaikh, A.A. (2016), "Consumer engagement and behavioural intention towards the continuous use of innovative mobile banking applications - Case study of Finland", in International Conference on Information Systems (ICIS-2016), Dublin, Ireland, December 11-14, 2016.

Hew, T. S. and Kadir, S. L. S. A. (2016), "Behavioural intention in cloud-based VLE: An extension to Channel Expansion Theory", Computers in Human Behavior, Vol. 64, pp. 9-20.

Hollebeek, L. D., Glynn M. S. and Brodie, R. J. (2014), "Consumer Brand Engagement in Social Media: Conceptualization, Scale Development and Validation”, Journal of Interactive Marketing, Vol. 28 No. 2, pp. 149-165.

Hsiao, C. H., Chang, J. J. and Tang, K. Y. (2016), "Exploring the influential factors in continuance usage of mobile social Apps: Satisfaction, habit, and customer value perspectives", Telematics and Informatics, Vol. 33 No. 2, pp. 342-355. 
Hulland, J., Baumgartner, H. and Smith, K. M. (2018), "Marketing survey research best practices: evidence and recommendations from a review of JAMS articles", Journal of the Academy of Marketing Science, Vol. 46 No. 1, pp. 92-108.

Ibrahim, N. F., Wang, X. and Bourne, H. (2017), "Exploring the effect of user engagement in online brand communities: Evidence from Twitter", Computers in Human Behavior, Vol. 72, pp. 321-338.

Islam, J. U., Rahman, Z. and Hollebeek, L.D. (2017), "Personality factors as predictors of online consumer engagement: an empirical investigation", Marketing Intelligence \& Planning, Vol. 35 No. 4, pp. 510-528.

Jalilvand, M. R., Ebrahimabadi, F. and Samiei, N. (2011), “The Impact of Branding on Customers' Attitudes toward Banking Services (The Case of Iran’s Melli Bank)”, International Business and Management, Vol. 2 No. 1, pp. 186-197.

Jayo, M., Diniz, E. H., Zambaldi, F. and Christopoulos, T. P. (2012), “Groups of services delivered by Brazilian branchless banking and respective network integration models", Electronic Commerce Research and Applications, Vol. 11 No. 5, pp. 504-517.

Jones, T., Taylor, S. F. and Bansal, H. S. (2008), "Commitment to a friend, a service provider, or a service company_are they distinctions worth making?", Journal of the Academy of Marketing Science, Vol. 36 No. 4, pp. 473-487.

Kemery, E. R. and Dunlap, W. P. (1986), "Partialling factor scores does not control method variance: A reply to Podsakoff and Todor", Journal of Management, Vol. 12 No. 4, pp. 525-530.

Khan, I., Rahman, Z. and Fatma, M. (2016), "The role of customer brand engagement and brand experience in online banking”, International Journal of Bank Marketing, Vol. 34 No. 7, pp. 1025-1041.

Kim, M. J., Kim, W. G., Kim, J. M. and Kim, C. (2016), “Does knowledge matter to seniors' usage of mobile devices? Focusing on motivation and attachment", International Journal of Contemporary Hospitality Management, Vol. 28 No. 8, pp. 1702-1727. 
Kongaut, C. and Bohlin, E. (2016), "Investigating mobile broadband adoption and usage: A case of smartphones in Sweden”, Telematics and Informatics, Vol. 33 No. 3, pp. 742-752.

Lepoutre, J. and Oguntoye, A. (2018), “The (non-) emergence of mobile money systems in Sub-Saharan Africa: A comparative multilevel perspective of Kenya and Nigeria”, Technological Forecasting and Social Change, Vol. 131, pp. 262-275.

Li, M., Dong, Z. Y. and Chen, X. (2012), "Factors influencing consumption experience of mobile commerce: A study from experiential view", Internet Research, Vol. 22 No. 2, pp. 120-141.

Liang, H., Saraf, N., Hu, Q. and Xue, Y. (2007), “Assimilation of enterprise systems: the effect of institutional pressures and the mediating role of top management", MIS Quarterly, Vol. 31 No. 1, pp. 59-87.

McLean, G. (2018), "Examining the determinants and outcomes of mobile app engagementA longitudinal perspective", Computers in Human Behavior, Vol. 84, pp. 392-403.

Mehrabian, A. and Russell, J. A. (1974), An Approach to Environmental Psychology, Cambridge, UK: MIT Press.

Midha, V. (2012), "Impact of consumer empowerment on online trust: An examination across genders", Decision Support Systems, Vol. 54 No. 1, pp. 198-205.

Mollen, A. and Wilson, H. (2010), "Engagement, telepresence and interactivity in online consumer experience: reconciling scholastic and managerial perspectives", Journal of Business Research, Vol. 63 No. 9/10, pp. 919-925.

Mothobi, O. and Grzybowski, L. (2017), "Infrastructure deficiencies and adoption of mobile money in Sub-Saharan Africa”, Information Economics and Policy, Vol. 40, pp. 71-79.

Mullan, J., Bradley, L. and Loane, S. (2017). Bank adoption of mobile banking: stakeholder perspective", International Journal of Bank Marketing, Vol. 35 No. 7, pp. 1154-1174. 
Murendo, C., Wollni, M., De Brauw, A. and Mugabi, N. (2018), "Social network effects on mobile money adoption in Uganda”, The Journal of Development Studies, Vol. 54 No. 2, pp. 327-342.

Oliver, R. L. (1997), Satisfaction: A behavioural perspective on the consumer, New York, NY: McGraw-Hill.

Oruç, Ö. E. and Tatar, Ç. (2017), “An investigation of factors that affect internet banking usage based on structural equation modelling", Computers in Human Behavior, Vol. 66, pp. 232-235.

Pansari, A. and Kumar, V. (2017), "Customer engagement: the construct, antecedents, and consequences", Journal of the Academy of Marketing Science, Vol. 45 No. 3, pp. 294-311.

Podsakoff, P. M., MacKenzie, S. B., Lee, J.-Y. and Podsakoff, N. P. (2003), "Common method biases in behavioural research: a critical review of the literature and recommended remedies", Journal of Applied Psychology, Vol. 88 No. 5, pp. 879-903.

Rawashdeh, A. (2015), "Factors affecting adoption of internet banking in Jordan: Chartered accountant's perspective", International Journal of Bank Marketing, Vol. 33 No. 4, pp. 510529.

Riley, E. (2018), “Mobile money and risk sharing against village shocks", Journal of Development Economics, Vol. 135, pp. 43-58.

Ringle, C. M., Wende, S. and Becker, J.M. (2015), "SmartPLS 3. Bönningstedt: SmartPLS. GmbH”, available at: http://www.smartpls.com (accessed December 15, 2018).

San-Martín, S., S., Prodanova, J. and López Catalán, B. (2016), “What makes services customers say “buy it with a mobile phone?”, Journal of Services Marketing, Vol. 30 No. 6, pp. 601-614. 
Shaikh, A. A., Karjaluoto, H. and Chinje, N. B. (2015), "Continuous mobile banking usage and relationship commitment-A multi-country assessment", Journal of Financial Services Marketing, Vol. 20 No. 3, pp. 208-219.

Smith, T.J. (2008), "Senior citizens and e-commerce websites: the role of perceived usefulness, perceived ease of use, and web site usability", Informing Science, Vol. 11 No. 1, pp. 59-83.

Tam, C. and Oliveira, T. (2016), "Performance impact of mobile banking: using the tasktechnology fit (TTF) approach”, International Journal of Bank Marketing, Vol. 34 No. 4, pp. 434-457.

Venkatesh, V., Morris, M. G., Davis, G. B. and Davis, F. D. (2003), “User acceptance of information technology: Toward a unified view”, MIS Quarterly, Vol. 27 No. 3, pp. 425-478.

Venkatesh,V., Morris, M. G. and Ackerman, P. L. (2000), “A longitudinal field investigation of gender differences in individual technology adoption decision-making processes", Organizational Behaviour Human Decision Process, Vol. 83, pp. 33-60.

Verhoef, P. C., Venkatesan, R., McAlister, L., Malthouse, E. C., Krafft, M. and Ganesan, S. (2010), "CRM in data-rich multichannel retailing environments: a review and future research directions”, Journal of Interactive Marketing, Vol. 24 No. 2, pp. 121-137.

Vivek, S. D., Beatty, S. E. and Morgan, R. M. (2012), “Customer engagement: Exploring customer relationships beyond purchase", Journal of Marketing Theory and Practice, Vol. 20 No. 2, pp. 122-146.

Vivek, S. D., Beatty, S. E. and Morgan, R. M. (2012), “Customer engagement: Exploring customer relationships beyond purchase", Journal of Marketing Theory and Practice, Vol. 20 No. 2, pp. 122-146.

Wirtz, J., den Ambtman, A., Bloemer, J., Horváth, C., Ramaseshan, B., van de Klundert, J., ... Kandampully, J. (2013), "Managing brands and customer engagement in online brand communities", Journal of Service Management, Vol. 24 No. 3, pp. 223-244. 
Zhou, T., Lu, Y. and Wang, B. (2010), “Integrating TTF and UTAUT to explain mobile banking user adoption”, Computers in Human Behavior, Vol. 26 No. 4, pp. 760-767. 


\section{List of Tables}

Table 1. Construct, indicators and loadings.

\begin{tabular}{|c|c|c|c|c|}
\hline Construct & Indicators & $\mathbf{M}$ & SD & Loadings \\
\hline Advocacy intention & I say positive things about MM to other people. & 5.25 & 1.61 & $0.884 * * *$ \\
\hline \multirow[t]{2}{*}{$\mathrm{CR}=0.93 \mathrm{AVE}=0.81$} & I recommend MM to someone who seeks my advice. & 5.29 & 1.43 & $0.912 * * *$ \\
\hline & I encourage friends and relatives to use MM. & 5.29 & 1.53 & $0.902 * * *$ \\
\hline Subjective norm & People who influence my behaviour think that I should use MM. & 4.49 & 1.61 & $0.902 * * *$ \\
\hline \multirow{2}{*}{$\mathrm{CR}=0.87 \mathrm{AVE}=0.69$} & People who are important to me think that I should use MM. & 4.64 & 1.63 & $0.920 * * *$ \\
\hline & People who I know use MM (NOM3). & 5.48 & 1.41 & $0.653 * * *$ \\
\hline Performance & I feel MM is useful. & 5.96 & 1.43 & $0.772 * * *$ \\
\hline expectancy & MM improves my payment efficiency. & 5.44 & 1.50 & $0.894 * * *$ \\
\hline \multirow[t]{2}{*}{$\mathrm{CR}=0.91 \mathrm{AVE}=0.73$} & MM improves my payment convenience. & 5.48 & 1.58 & $0.896^{* * *}$ \\
\hline & MM allows me to make payments more quickly. & 5.67 & 1.47 & $0.842 * * *$ \\
\hline Effort expectancy & Learning how to use MM is easy for me. & 5.76 & 1.44 & $0.893 * * *$ \\
\hline \multirow{3}{*}{$\mathrm{CR}=0.92 \mathrm{AVE}=0.75$} & It is easy for me to use MM. & 5.89 & 1.36 & $0.916^{* * *}$ \\
\hline & It is easy for me to use MM skillfully. & 5.54 & 1.46 & $0.879 * * *$ \\
\hline & Using MM saves me a lot of time. & 5.83 & 1.47 & $0.763 * * *$ \\
\hline Cognitive processing & Using MM gets me to think about the service. & 4.67 & 1.51 & $0.833 * * *$ \\
\hline \multirow[t]{2}{*}{$\mathrm{CR}=0.88 \mathrm{AVE}=0.71$} & I think about MM a lot when I'm using this service. & 4.46 & 1.48 & $0.862 * * *$ \\
\hline & Using MM stimulates my interest to learn more about this service. & 4.52 & 1.50 & $0.840 * * *$ \\
\hline Affect & I feel very positive when I am using MM service. & 4.93 & 1.41 & $0.885^{* * *}$ \\
\hline \multirow[t]{3}{*}{$\mathrm{CR}=0.94 \mathrm{AVE}=0.81$} & Using MM service makes me happy. & 4.83 & 1.42 & $0.919 * * *$ \\
\hline & I feel good when I am using MM service. & 4.89 & 1.41 & $0.921 * * *$ \\
\hline & I am proud to use MM service. & 4.87 & 1.49 & $0.873 * * *$ \\
\hline Continuous usage & I intend to continue using MM rather than discontinue its use. & 5.23 & 1.66 & $0.909 * * *$ \\
\hline $\mathrm{CR}=0.91 \mathrm{AVE}=0.83$ & My intentions are to continue using MM rather than use any alternative means. & 4.64 & 1.76 & $0.914 * * *$ \\
\hline
\end{tabular}




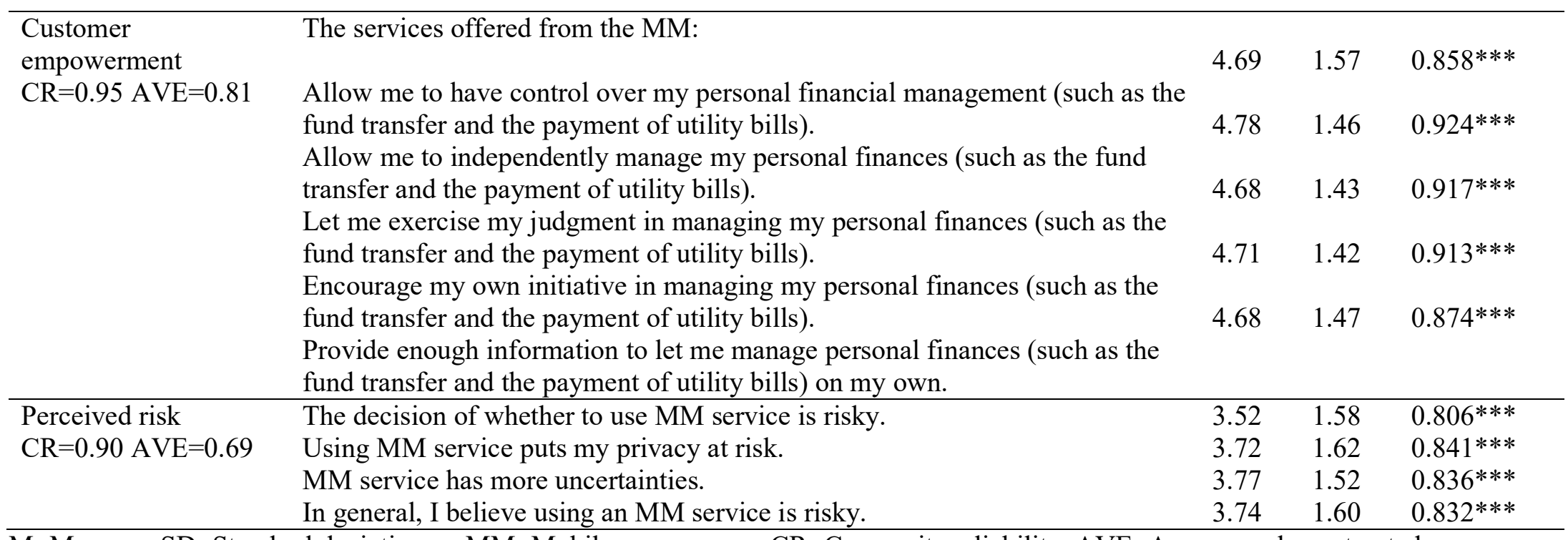

$\mathrm{M}=$ Mean $\quad \mathrm{SD}=$ Standard deviation $\quad \mathrm{MM}=$ Mobile money $\quad \mathrm{CR}=$ Composite reliability $\mathrm{AVE}=\mathrm{Average}$ value extracted

$* * * p<0.001$ (two-tailed) 
Table 2. Demographic characteristics $(n=595)$.

\begin{tabular}{|c|c|c|}
\hline $\begin{array}{l}\text { Demographic } \\
\text { characteristics }\end{array}$ & Frequency & Percen \\
\hline \multicolumn{3}{|l|}{ Gender } \\
\hline Males & 316 & 53.1 \\
\hline Females & 279 & 46.9 \\
\hline \multicolumn{3}{|l|}{ Age (years) } \\
\hline $18-25$ & 356 & 59.8 \\
\hline $26-35$ & 173 & 29.1 \\
\hline $36-45$ & 48 & 8.1 \\
\hline $46-55$ & 15 & 2.5 \\
\hline $56-65$ & 3 & 0.5 \\
\hline \multicolumn{3}{|l|}{ Highest level of education } \\
\hline Junior High School & 9 & 1.6 \\
\hline Senior High School & 137 & 23 \\
\hline O' Level / A' Level & 11 & 1.8 \\
\hline Polytechnic & 17 & 2.9 \\
\hline Teacher training & 4 & 0.7 \\
\hline Bachelor /Master & 414 & 69.5 \\
\hline Ph.D. & 3 & 0.5 \\
\hline \multicolumn{3}{|c|}{ Current employment status } \\
\hline Student & 346 & 58.2 \\
\hline Employee/professional & 229 & 38.5 \\
\hline Unemployed & 7 & 1.2 \\
\hline Entrepreneur & 13 & 2.2 \\
\hline \multicolumn{3}{|l|}{$\begin{array}{l}\text { Usage frequency of cell } \\
\text { phones }\end{array}$} \\
\hline$<1$ year & 117 & 19.7 \\
\hline $1-3$ years & 159 & 26.7 \\
\hline $4-6$ years & 150 & 25.2 \\
\hline 7 - 9 years & 74 & 12.4 \\
\hline $10-12$ years & 32 & 5.4 \\
\hline $13-15$ years & 17 & 2.9 \\
\hline$>15$ years & 46 & 7.7 \\
\hline \multicolumn{3}{|l|}{ MM Usage experience } \\
\hline$<1$ month & 85 & 14.3 \\
\hline $1-4$ months & 92 & 15.5 \\
\hline $5-8$ months & 82 & 13.8 \\
\hline $9-12$ months & 118 & 19.8 \\
\hline $13-16$ months & 69 & 11.6 \\
\hline $17-20$ months & 37 & 6.2 \\
\hline$>20$ months & 112 & 18.8 \\
\hline
\end{tabular}


Table 3. Path coefficient and VIF $(n=595)$.

\begin{tabular}{lllll}
\hline Criterion & Predictor & $\boldsymbol{\beta}$ & t-value\# & VIF \\
\hline Cognitive processing & Consumer empowerment & 0.07 & 1.55 & 1.29 \\
& Subjective norm & 0.26 & $6.18^{* * *}$ & 1.32 \\
$\mathrm{R}^{2}=0.31$ & Performance expectancy & 0.13 & $2.57^{* *}$ & 1.99 \\
& Effort expectancy & 0.25 & $5.40^{* * *}$ & 1.80 \\
& Perceived risk & 0.11 & $2.77^{* *}$ & 1.01 \\
\hline \multirow{3}{*}{ Affect } & Consumer empowerment & 0.17 & $3.95^{* * *}$ & 1.29 \\
& Subjective norm & 0.20 & $5.37^{* * *}$ & 1.32 \\
$\mathrm{R}^{2}=0.45$ & Performance expectancy & 0.24 & $4.88^{* * *}$ & 1.99 \\
& Effort expectancy & 0.22 & $4.58^{* * *}$ & 1.80 \\
& Perceived risk & -0.14 & $3.87^{* * *}$ & 1.01 \\
\hline \multirow{3}{*}{$\mathrm{Advocacy}$ intention } & Cognitive processing & 0.11 & $2.16^{*}$ & 1.68 \\
& Affect & 0.46 & $8.02^{* * *}$ & 1.83 \\
$\mathrm{R}^{2}=0.39$ & Perceived risk & -0.07 & $2.03^{*}$ & 1.11 \\
& Education & -0.04 & 1.29 & 1.12 \\
& Usage experience & 0.07 & 1.79 & 1.24 \\
& Usage frequency & 0.10 & $2.60^{* *}$ & 1.33 \\
& Income & 0.10 & $2.47^{*}$ & 1.40 \\
$\mathrm{R}^{2}=0.33$ & Age & 0.02 & 0.35 & 1.39 \\
\hline \multirow{3}{*}{ Continuous usage } & Cognitive processing & -0.03 & 0.51 & 1.69 \\
& Affect & 0.39 & $6.87^{* * *}$ & 2.17 \\
& Perceived risk & -0.03 & 0.70 & 1.12 \\
& Education & -0.00 & 0.02 & 1.12 \\
& Usage experience & 0.01 & 0.34 & 1.25 \\
& Usage frequency & 0.06 & 1.41 & 1.35 \\
& Income & 0.01 & 0.13 & 1.42 \\
& Age & -0.03 & 0.67 & 1.40 \\
\hline & & & &
\end{tabular}

Note: \# Based on 1000 bootstrapping samples;

$* * * p<0.001, * * p<0.01, * p<0.05$ (two-tailed) 
Table 4. Summary of findings (antecedents and consequences of customer engagement).

\begin{tabular}{lll}
\hline Associations & Sign & Results \\
\hline Antecedent hypotheses & & \\
Consumer empowerment $\rightarrow$ Cognitive processing (H1a) & + & Not supported \\
Subjective norm $\rightarrow$ Cognitive processing (H1b) & + & Strongly Supported \\
Performance expectancy $\rightarrow$ Cognitive processing (H1c) & + & Supported \\
Effort expectancy $\rightarrow$ Cognitive processing (H1d) & + & Strongly Supported \\
Perceived risk $\rightarrow$ Cognitive processing & + & Supported \\
Consumer empowerment $\rightarrow$ Affect (H2a) & & Supported \\
Subjective norm $\rightarrow$ Affect (H2b) & + & Strongly Supported \\
Performance expectancy $\rightarrow$ Affect (H2c) & + & Strongly Supported \\
Effort expectancy $\rightarrow$ Affect (H2d) & + & Strongly Supported \\
Perceived risk $\rightarrow$ Affect & - & Supported \\
\hline Consequent hypotheses & & \\
Cognitive processing $\rightarrow$ Advocacy intention (H3a) & + & Supported \\
Cognitive processing $\rightarrow$ Continuous usage (H3b) & + & Not Supported \\
& & \\
Affect $\rightarrow$ Advocacy intention (H4a) & + & Strongly Supported \\
Affect $\rightarrow$ Continuous usage (H4b) & + & Strongly Supported \\
\hline
\end{tabular}




\section{List of Figures}

Figure 1 Mobile money services as a new business model driven by technology.

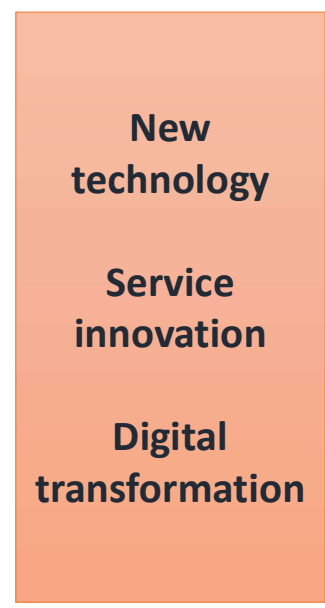

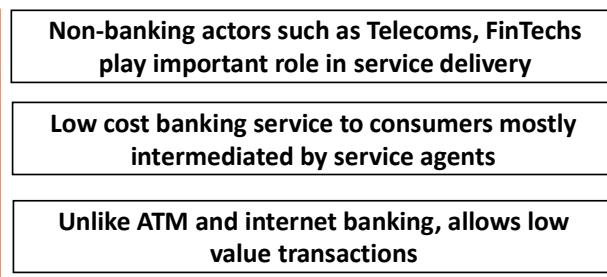

Limited services (funds transfer, utility payments) but future options for other service designs

Targeted at unbanked segments with low access to conventional or formal banking services

MMS business model can be led by bank, nonbank or Telecom service provider

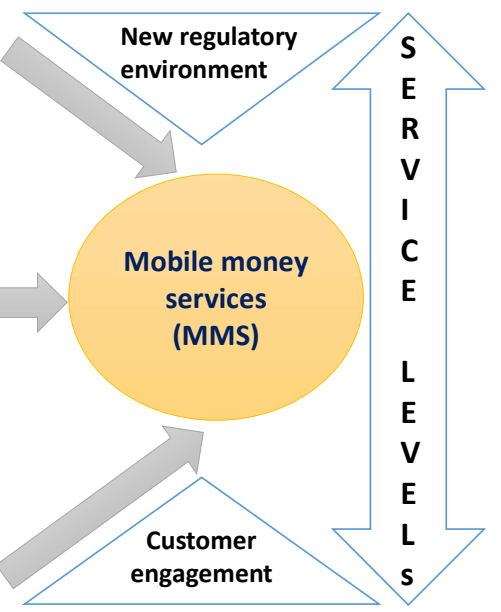


Figure 2 Conceptual model.

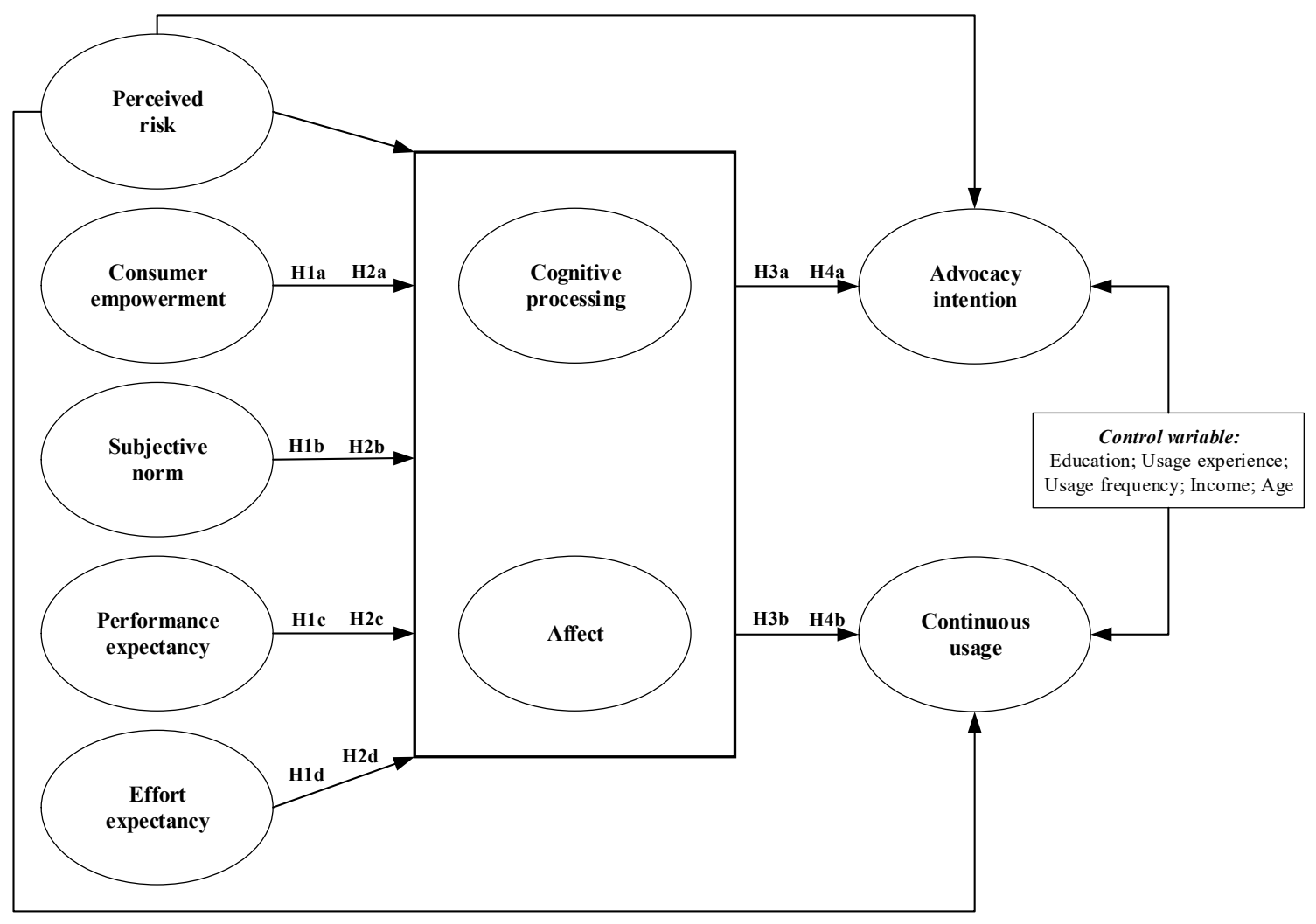


Figure 3 Structural model results.

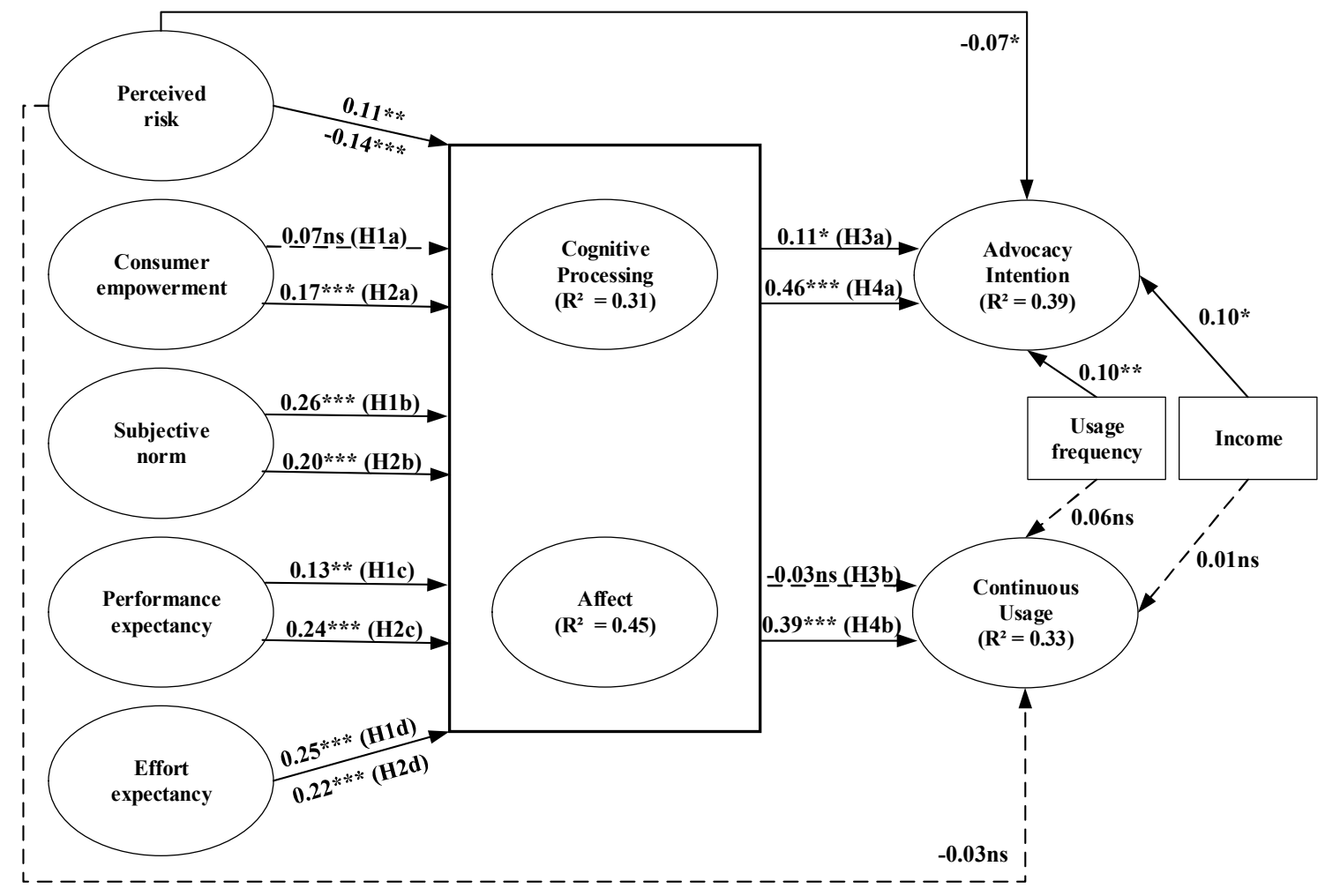

